\title{
A Brief Perspective on Acacia a Member of Family Leguminosae
}

Jyoti Chauhan ${ }^{1}$ Ishan Saini ${ }^{1}$, Tarun Kumar ${ }^{2 *}$ and Prashant Kaushik ${ }^{3,4^{*}}$

${ }^{1}$ Department of Botany, Kurukshetra University Kurukshetra, 136119Kurukshetra, India

${ }^{2}$ Department of Forestry, Chaudhary Charan Singh Haryana Agricultural University, 125004Hisar, India

${ }^{3}$ Instituto de Conservación y Mejora de la Agrodiversidad Valenciana, Universitat Politécnica de valencia, 46022 Valencia, Spain

${ }^{4}$ Nagano University, 1088 Komaki, Ueda, 386-0031 Nagano, Japan

Email: tarunsingh.tarun88@gmail.com prakau@doctor.upv.es

\section{Abstract}

Tree members of the genus Acacia have benefits that are obvious for enhancing soil fertility in farming, forestry and agroforestry in regions with nutrient-poor soils, and for restoring degraded ecosystems and lands. Nevertheless, the species of the genus Acacia have got the potential to bring about significant adverse impacts on biodiversity or ecosystem functioning when it gets invasive. The ecology of the species in nearly all areas of its created range remains poorly understood. Here we have compiled the information regarding the importance, cultivation and the production of important species of genus Acacia. We hope this information will be useful to get awareness about the crucial trees in the genus Acacia.

Keywords: Acacia, cultivation, diseases, insect pest

\section{Introduction}

Acacia commonly called Acacias or Wattles is a common species found in dry, arid and semi-arid areas and also in the low-lying mountainous forest that belong to subfamily: Mimosoideae of the third-largest family Fabaceae (Pea family). It includes lianas, shrubs and towering trees. The term Acacias, given by Miller (1754) which come from an ancient Greek word 'Akakía' meaning "thorny Egyptian tree" or "Shittah tree (used in Hebrew Bible to refer trees wildly growing in Sinai desert and the Jordan valley, belonging to Vachellia (=Acacia) and Faidherbia genus)" attested before 1398. Akakía is a word of uncertain origin probably it is related to the Egyptian word 'Ake' meaning thorny or sharp point (Lewis and Short, 1879). Word' Wattle' was given by ancient tribe, Teutonic that means 'to weave' ${ }^{1}$. To date its complete actual origin of the name is unknown. Acacias are native to Australia and Africa which evolved as fire-resistant plants about twenty million years ago, with $A$. niloticaas the first species reported by Linnaeus.

The Wattle plant has more than 1350 species which can be broadly divided into two groups with 5 genera (early, there were 6) comprises of around 960 genera in Australia still retained the genus Acacia. One group of Acacias are having simple leaves containing Phyllodes (petiole develop into leaf-like appearance and function) with or without stipular spines. The second group has compound fern-like bipinnately dissected leaves with or without stipular spines and stem prickles, found in Australia, Africa and the USA. The plant starts spreading from these places to other countries where fire and dry conditions are prevalent. The plant started colonizing and began to 
form scrublands in the dry, open forest along with several other plants, namely Allocasuarina, Callitris and Eucalyptus ${ }^{2}$.

The five genera officially adopted are Acacia itself, then Vachellia, Acaciella, Mariousousa and Senegalia. They are differentiated based on their habit pattern, from small shrubs to large canopy covered trees. Some group of botanists disagreed in dividing Acacias into these genera instead they proposed Racospermafor this genus, but now this is accepted elsewhere. Acacias have proved to be keystone species in several arid areas ${ }^{3,4}$. Fossilized pods of $A$. parschlugiana and $A$. cyclosperma were found during the Tertiary period from Switzerland. About twenty-five million years ago, fossilized pollens of Acacia had been recorded from Oligocene in Australia. The fossilization information gives an idea that the plant is distributed in woodlands, scrublands, rainforests, deserts, grasslands and savannas, comprises of almost all parts of the world. Acacias have traditional values in pharmaceuticals, timber, gum, dye and food industries. They are grown wildly in an arid climate or as cultivated around homes or agricultural fields ${ }^{5}$.

\section{A.nilotica (L.) Del. [syn. A. arabica (Lam.)/Vachellia nilotica (L.) P.J.H.Hurter \& Mabb}

It is a middle-sized deciduous, but a perennial tree with thorny branches found mainly in hot, arid or dry low-lands, having dark-brown to black, thick, longitudinal fissured, rough and deeply ridged/grooved bark and feathery crown-like round and moderately dense canopy of 12-15 m height. The bark is having low-quality gum of reddish colour. Stems are pubescent with purplishbrown, compact and lenticellate branchlets. Leaves are 3-4 cm long having 12-16 tiny smooth leaflets which are present on alternate; bipinnately dissected, tomentose side-stalks with cupshaped glands at junctions of last pinnulae (4-8 pairs) of 2-6 mm. Tree shed its leaves in March or April which quickly renewed. Thorns are straight, long, slender, ivory white present in 7-12 pairs of 3-5 cm length and axil in position making an angle of around $100-120^{6}$.

The inflorescence is globulus cymose head of 10-13 mm diameter made up of hundreds of minutes, golden-yellow, prolific, campanulate penta-gamosepalous, penta-gamopetalous, polyandry (many, stalked, small), actinomorphic, ebracteate, sessile flowers on 2-3 cm peduncle with axillary or whorly in position. Flowers have monocarpous, superior, unilocular ovary. Pods are fleshy green when young and become black and hard at maturity, which is indehiscent. Pod dispersed through animals who brows on them. Seeds are 10-14 in number arranged in a single row which are smooth, areole (small bumps), sub-circular, blackish brown with 5.5-7.2 mm long and 5-5.7 mm wide. Their number ranges from 8,000 to 15,000 seeds per $\mathrm{kg}^{7}$.

\section{A. catechu Willd. [syn. Senegalia catechu (L. f.) P.J.H. Hurter \& Mabb]}

It is a moderately-sized, gregarious, deciduous, thorny, perennial fast-growing tree (up to 10 years then show slow growth) found in the riverain area under arid areas, having peeling dark greyishbrown, thick, rough bark that peels off when mature with spreading elongated-feathery crown canopy, attaining a height up to $15 \mathrm{~m}$. Bark is deeply cracked and flaking off in long, narrow, rectangular, vertical strips at maturity (which is a diagnostic feature), otherwise young plant has corky bark. Stems are slender, glabrous, shining, brownish-red, puberulous, small branchlets which 
are armed with false inconspicuous stipular spines present in pairs below the petioles with slightly infra axillary position and have no leaves on flowering branchlets, occasionally. Leaves are 4-9 mm long, subulate, stipulate, alternate, straight or hooked, bipinnate with 10-30 pairs of tiny, bluntended, pilose (small hairy) leaflets of 3-5 mm long. Between the first pair of leaves, large oval glands are present ${ }^{8,9}$.

Thorns are shiny, stout, curved, reddish-brown, present in pairs of around $10 \mathrm{~mm}$, present at the base of each leaf. The inflorescence is spiked (6-13 cm long) present in a cluster of 1-4, pedunculated with numerous tiny whitish-yellow, sessile, bracteate, cupular-campanulate calyx, polyandry, flowers. Calyx and petals are pale green. Stamens are long and brush-like, giving the colour of flowers ${ }^{7}$. The fruit is a flat pod of $10 \mathrm{~cm}$ long, thin, straight, irregular and sinuate along margins with pointed ends. Each pod are magenta when young, become dark golden-brown and dehiscent when mature that contain 4-7 seeds. Seeds are brown, orbicular or ovate but flat having 5-7 mm diameter.

\section{A. leucophloea (Roxb.) Willd. [syn. Vachellia leucophloea (Roxb.) Maslin, Seigler \& Ebinger]}

It is a moderately-sized, thorny, deciduous tree, found in the hot dry forests, having, rough, yellowish-brown bark with an umbrella-like crown canopy of 20-25 m height. The plant has a twisted, stout and crooked trunk with several wide branches. Bark has pale-yellow patches (which is a diagnostic feature). Stems are erect, smooth, solid, greyish-white, rough, branched, slender and excorticating in irregular scale at maturity. Thorns present in pairs of $2-4 \mathrm{~cm}$ long, axial, straight, puberulous and brownish-red in colour.

Leaves are alternate, $2.7-4.6 \mathrm{~cm}$ long, stipulate, bipinnate, linear, oblong, pinnae 6-10 pairs of 3.4$5.7 \mathrm{~cm}$ with a gland between 3-4 pinnae, having many (30-50) opposite, sessile leaflets. The inflorescence is terminal panicle-heads with pedunculate, actinomorphic, conspicuous, hermaphrodite, complete, yellowish-white flowers. Fruits are flat, linear or oblong, yellowishgreen-khaki coloured, velvety pods $(8-18 \mathrm{~cm})$, slightly curved, tomentose, tardily dehiscent having 8-12 seeds. Seeds are lodged in separate compartments, ovate, minute, smooth, pale-brown with 5.4-6.2 ×3.5-4.3 $\mathrm{mm}$ dimensions.

\section{A. tortilis (Forsk.) Hayne [syn. Vachellia tortilis (Forsk.) Galasso \& Banfi.]}

It is a small to medium-sized deciduous to an evergreen tree, found in tropical thorn forest of arid regions having reddish-brown, fissured, rough, bark with rounded, spreading umbrella-like canopy (flat-topped) of 5-12 m height, occasionally of 19-21 m. Stems have glabrous to subglabrous, dense, hairless (sometimes velvety-hairy), spinescent-stipulate, dense branchlets when young, become brown to purplish-black when mature. Leaves of $2.5 \mathrm{~cm}$ are double compound, alternate with short rachis having 5-11 pairs of glabrous to pubescent leaflets (5-15 $\mathrm{mm}$ ) and 10-20 pair of pinnae. Thorns are of two types, short: brownish, curved or hooked of 5 $\mathrm{mm}$ and long: straight, paired, ivory-white, slender of $8 \mathrm{~cm}$. The inflorescence is axillary cymosehead (0.6-1.2 cm diameter) having high aroma with small, whitish-cream, actinomorphic, hermaphrodite, complete flowers on $0.4-2.4 \mathrm{~cm}$ long peduncles. The fruit is contorted or spirally 
twisted, hairy, longitudinally-veined, brown-coloured pods. Seeds are smooth, flattened but coiled into a spring-like or elliptical structure, compressed, olive to reddish-brown of $6.5-7.2 \times 4.6-5.8$ $\mathrm{mm}$ size.

\section{A. farnesiana [syn. Vachellia farnesiana (L.) Wight et Arn./A. smallii Isely]}

It is a small-sized, thorny, evergreen to a deciduous or semi-deciduous shrub or small tree, found in a tropical and sub-tropical area, having rough, light brown bark with the spreading canopy of 2-5 m height, usually of 7-9 m. Stems are slender, chocolatey-brownish-grey, hairless, spinescent, lenticellate, glabrous to purplish-grey, terete branches, generally show multiple trunks. Thorns are usually short, up to $1.5-1.8 \mathrm{~cm}$ long, ivory-white and present in pairs. Leaves are alternate, leathery, tomentose with 2-6 paired pinnae having 10-12 leaflets of 2-7 mm minute leaflets. The inflorescence is axillary pedunculate heads, scented, sessile, pentamerous, golden-yellow flowers and fruits are straight or curved, indehiscent pods of $4.6-7.2 \mathrm{~cm}$ long. Seeds are smooth, thick, chestnut-brown, elliptical which are embedded in a dry, spongy tissue of 7-8 mm long.

\section{A. auriculiformis A. Cunn. ex Benth [syn. A. moniliformis Griseb]}

It is a moderately-sized, fast-growing, crooked, evergreen, thorn-less tree, glaucous when young, generally cultivated, having grayish-white, vertically fissured, bark with drooping often multistemmed branches of 16-25 m height. Stems are erect, branched, initially smooth then become fissured with dense foliage. Leaves are alternate, simple and modified into phyllodes which are blade-like, pointed at both ends, coriaceous, and curved or sickle-shaped. The inflorescence is densely rigid spikes $(7-9 \mathrm{~cm})$ of yellowish-orange colour with loose, scented, long, campanulatecalyx, hermaphrodite, actinomorphic, complete flowers. The fruit is flat, glaucous, cartilaginous, oblong pods which become twisted at maturity. They have transversely veined with undulate margins which can have about 47,000 black shining seeds per $\mathrm{kg}$. Seeds are transversely placed in the pods which are ovate to elliptical of 5-6 $\times 4-5 \mathrm{~mm}^{10}$.

\section{Acacia plantation}

Acacia plantation needs no particular nutrient and can grow on any type of well-drained soil with vey less watering (once in a week). Naturally, Acacia can grow on acidic, alkaline, dry and hot soil conditions. But, during cultivation soil can be mixed carefully with pine barks to avoid any type of rot or mulched with any other available material which can prevent drying out, at initial stages. For garden plantation, plantlets can grow in pots before increasing in the field and should not be kept for long because the roots become long, very quickly ${ }^{11}$. After seedlings developed in pots hole is dug twice the size of the pot and fill with water twice and allow it to drain away each time. Place the plantlets grown in pots in the hole fill it with soil and water at the end. Seedlings are planted at 2-3 $\mathrm{m}$ distance, and pruning is done each year after flowering to give the bushy appearance. For commercial purpose filed is of several hundred hectares, the following step are to be taken into consideration ${ }^{12}$. 


\section{Seed collection and preparedness}

Seeds have shelf-life 6-8 months which are collected from mature and healthy trees, after the pods start cracking (best time for collection). Seeds are collected fromNovember to the end of January when they are green. This reduces the degree of pathogenicity during seedling growth. For judging the seeds whether they are healthy or not, leave the harvested pods to dry under sunlight for a day or so. If the pods remain turgid and turn dark, it would be a wise decision to collect the seeds.

On the other hand, if seeds lose their water in the pods and become flaccid, then reject those pods. They were washed under running water and with boiling water and allowed to cool for 24 hours at room temperature. If the seeds have to store either due to unavailability of suitable climate or limited nursery acclimatizing, then proper fumigation of the chamber and appropriate conditions should be given, and seeds are kept in either glass, plastic or tin moisture-proof jars. But the seeds should sow because the storage food becomes less due to respiration. It is advisable to treat the jars with some insecticidal powders. Generally, pyrethrin and benzene hexachloride based. Therefore, they are usually stored in dry, airtight containers. In several practices, the seeds of Acacia are treated by soaking into sulphuric acid ${ }^{13}$.

\section{Nursery practices}

It is essential to select the site of nursery construction, free from any type of soil-borne diseases or harmful fungi and nematodes or pests, to raise the seedlings. The sunlight availability should be fulfilled, and sandy, loamy drained soil should present, adequate irrigation and proper drainage system. Its location should be near-by where Acacia seedlings have to be planted on the fields and near the metal road. This inevitably reduces the impact of transportation shock to the seedlings and facilitate easy transport on roads, and also transport expense become less. Along with this, skilled labour should be satisfactory in the area. The area should not be flooded during the rainy season; enough level has to be maintained ${ }^{14}$. Raising the level of the nursery, protection against wind cane be sheltered by growing high canopy coverage trees. By this, excessive hotness during the day is also controlled. Proper weeding in the nursery should be done time-to-time, to stop secondary host pathogens and to decrease the water-use efficiency.

\section{Sowing}

Pretreated seeds are raised in a nursery, two seeds are sown at 1-2 cm depth in each container and within 3-4 days seedlings start growing. Generally, this step is done in the month of February when winters start ending. Soil is mixed with sand, farmyard manure and clay soil. Seedlings of around $25-35 \mathrm{~cm}$ plantlets are transferred to bags and planted in the fields. This pre-sowing treatment is necessary because the seed-coat is hard, which is impervious to water. They are now ready for transplant. No unique fertilization is required for seedlings Acacia. Pits of $0.5 \times 0.5 \times 0.5$ $\mathrm{m}$ are dug before the start of rains.

\section{Harvesting}


Trees with girth of $70-110 \mathrm{~cm}$ are suitable for harvesting.

\section{Weeding}

In the arid zone, moisture content plays essential role for forestry. 6-8 weeks after planting, weeds usually start growing and this has to be planted-out. It is essential to uproot the weeds at the proper time before flowering. There is less chance of spreading of plant. Hoeing is done from time to time to prevent moisture loss and improve aeration.

\section{Thinning and Pruning}

For proper growth of plant pruning is done each year to give the bushy appearance.

\section{Diseases}

Several pests infest these trees and decrease their valuable products causing economic losses. So, it becomes necessary to recognize these pests and diseases and mitigate them in nurseries ${ }^{16}$.

Fungal diseases

Alternaria Tip Necrosis

Causative agent: Alternaria alternata

Symptoms: Drying of phyllode tips, yip necrosis, dark tan lesions which enlarge and coalesced to form large necrotic areas ${ }^{16}$.

Species affected: Acacia aulacocarpa, A. crassicarpa, A. mangium, A. auriculiformis, A. nilotica, $A$. catechu

1. PESTALOTIOPSIS TIP NECROSIS AND FOLIAR SPOT

Causative agent: Pestalotiopsis sp.

Symptoms: Tip necrosis, no defoliation, elongated brown spots, leaf necrosis.

Species affected: Acacia aulacocarpa, A. crassicarpa, A. mangium, A. auriculiformis,

A. nilotica, $A$. senegal

2. COLLETOTRICHUM TIP NECROSIS AND FOLIAR SPOT

Causative agent: Glomerella cingulata (imperfect form = Colletotrichum gloeosporioides)

Symptoms: Seedling Blight, dark brown spots with pale margins near the phyllode tip, occasionally dark fungal fruitifications of causal organism at some spots.

Species affected: Acacia aulacocarpa, A. crassicarpa, A. mangium, A. auriculiformis,

A. catechu

3. PHOMOPSIS FOLIAR SPOT (SHOOT BLIGHT)

Causative agent: Phomopsis sp.

Symptoms: small greyish amphigenous spots on phyllode, premature abscission, the spots enlarge and cover the lamina ${ }^{17}$.

Species affected: Acacia aulacocarpa, A. crassicarpa, A. auriculiformis, A. catechu 


\section{SPORIDESMIUM FOLIAR SPOTS}

Causative agent: Sporidesmium australiensis

Symptoms: Premature defoliation, dark brown spots on phyllode which turn pale, premature abscission

Species affected: Acacia aulacocarpa

\section{CURVULARIA TIP NECROSIS}

Causative agent: Curvularia

Symptoms: greyish light brown spots, premature defoliation

Species affected: Acacia crassicarpa, A. mangium

\section{SOOTY MOULD (BLACK MILDEW)}

Causative agent: Meliola sp.

Symptoms: affected phyllodes have dark brown to greyish-black superficial growth, premature defoliation

Species affected: Acacia crassicarpa, A. nilotica, A. catechu

\section{CERCOSPORIDIUM FOLIAR SPOT}

Causative agent: Cercosporidium acaciae

Symptoms: Premature defoliation, extensive spotting, spots increase in size and coalesced to form large necrotic spots, the infection can reach veins too.

Species affected: Acacia mangium

\section{CERCOSPORELLA FOLIAR SPOT}

Causative agent: Cercosporella theae

Symptoms:dark sunken lesions in leaves and stem, defoliation.

Species affected: Acaciamangium, A. catechu

\section{EXSEROHILUM FOLIAR SPOT}

Causative agent: Exserohilum rostratum

Symptoms: dark irregular lesions with pale centres on foliage.

Species affected: Acaciamangium, A. auriculiformis

10. PINK DISEASE

Causative agent: Corticum salmonicolor

Symptoms: yellowing and wilting of phyllodes, defoliation.

$10 \%$ mortality rate has been reported due to pink disease (Florence and balasunderan ,1991)

Species affected: Acacia auriculiformis, A. nilotica

\section{PHOMA FOLIAR SPOT}

Causative agent: Phoma sp.

Symptoms: Elongated streak like white lesions which coalesced into irregular shaped lesions, black dot like pycnidia seen in lesions. 
Species affected: Acaciaauriculiformis, A. catechu

12. POWDERY MILDEW

Causative agent: Oidium sp.

Symptoms:white powdery mass on upper sur face, gradually ascends to lower surface too.

Species affected: Acacia mangium, A. auriculiformis, A. catechu

13. HEART ROT

Causative agent: Fomes badius

Symptoms:Sophophores develop on the bark,Fungus causes decay in the heart wood, initially it changes colour to deep brown later turning yellow, spongy and mottled, it becomes difficult to extract cutch or kattha due to its complete disintegration.

Species affected: Acacia catechu

\section{HANDERSONULA DIEBACK}

Causative agent: Handersonula sp.

Symptoms: initially yellowing of phyllode, thinning of crown, defoliation, dieback of branches, death of main branch of crown, development of epicormic shoots giving branchy appearance. Infection progresses, killing the epicormic shoots and ultimately the tree.

Species affected: Acacia mangium, A. auriculiformis

15. GLIOCLADIUM STEM CANKER

Causative agent: Gliocladium sp.

Symptoms: basal stem canker characterized by appressed bark on one side, stem tissues show typical browning. With the advancement of decay, the shoot shows yellowing of phyllodes, defoliation, thinning of crown and ultimately death. Partial infection is seen in trees infested with Xylebolus.

Species affected: Acacia mangium

\section{CYLINDEROCLADIUM FOLIAR SPOT}

Causative agent: Cylindrocladim quiqueseptatum (seedling), C. scoparium (young and adult shoots)

Symptoms:foliar spotting in seedling, reddish brown necrotic areas usually around the margins, tips abscess prematurely

Species affected: Acacia mangium, A. auriculiformis, A. nilotica

\section{STEM RUST}

Causative agent: Uromyces digitatus

Symptoms:stunted growth of shoot, sometimes gall develop.

Species affected: Acacia auriculiformis, A. nilotica 
18. BRANCH CANKER

Causative agent: Cytospora sp.

Symptoms:extensive mortality, initially develop as depression on one side of branch, tissue in the depressed area die and gradually spreads to whole of branch, eventually the branch dies.

Species affected: Acacia aulacocarpa

19. ARMILLARIA ROOT ROT

Causative agent: Armillaria mellea

Symptoms: Yellowing or browning of phyllode, leaf drop, stunted growth, gummosis, root death, dieback

Species affected: Acaciaauriculiformis, A. nilotica

20. POLYPORUS ROOT ROT

Causative agent: Polyporus gilvus

Symptoms: Yellowing or browning of phyllode, leaf drop, root death, dieback Species affected: Acacia nilotica

\section{RED ROT DISEASE}

Causative agent: Ganoderma lucidium

Symptoms: Yellowing of phyllode, defoliation and death of branches in the upper crown, slowly spreads to epicormic shoots and the dying main stem of the tree. The root tissue shows extreme browning, fruitification of fungus at the base of dead roots. The fungus produces a thin white layer between bark and wood.

Species affected: Acacia mangium, A. auriculiformis, A. nilotica, A. catechu

\section{BASAL STEM CANKER AND ROOT DECAY (COLLAR ROT)}

Causative agent: Botryodoplodia theobromae

Symptoms:appressed bark cracks, discoloured sapwood and dead with zonation lines, roots on the side of canker were dead with black zonation lines. The dead bark and tree parts are susceptible to termite infestation.

Species affected: Acacia crassicarpa, A. nilotica

\section{BROWN ROT DISEASE}

Causative agent: Phellinus noxius

Symptoms:stunting, chlorosis, wilting, dieback of roots ultimately death of tree.

Species affected: Acacia mangium, A. auriculiformis, A. catechu

\section{CHARCOL ROT}

Causative agent: Macrophomina phaseolina

Symptoms: Dark brown, purplish brown amphigenous spots mostly at leaf margins, occasionally laminar spots, dieback, gummosis, root death

Species affected: Acacia aulacocarpa, A. crassicarpa, A. mangium, A. auriculiformis, A. nilotica, A. Senegal, A. catechu 


\section{NEW WILT DISEASE}

Causative agent: Fusarium oxysporus

Symptoms:damping off, wilting, chlorosis.

Species affected: Acacia auriculiformis, A. nilotica, $A$. catechu

\section{POD ROT}

Causative agent: Fusicoccum sp.

Symptoms: Dull purplish spots on green pods especially in middle and lower parts of the crown, affected pods are dried up and shed prematurely, seeds inside pods found shrivelled and brown.

Species affected: Acacia auriculiformis

\section{Insects Pests}

1. Anacardium melanorhodon

Common name: Tree locust

Tissue damaged: leaves and a young green plant.

Effect: Defoliation reduces gum production.

Species affected: Acacia senegal

2. Sphenoptera chalcichroa arenosa

Common name: Silver tree borer

Tissue damaged: wood

Effect: the insect bores into the timber cambium layer of branches.

Species affected: Acacia nilotica, $A$. catechu

3. Sphenoptera fulgens

Common name: Root boring borer

Tissue damaged: root

Effect: the insect bores into the root damaging xylem tissue causing dieback and gradual tree mortality. The timber production is affected.

Species affected: Acacia nilotica, $A$. catechu

4. Bruchus gonagra (Caryedon gonagra)

Common name: Seed weevil

Tissue damaged: pods and seed

Effect: The adults lay eggs on the pods and then the larvae bore into the seed, often wholly destroying the seed and hence preventing germination.

Species affected: Acacia nilotica, $A$. catechu

\section{Bruchidius uberatus}

Common name: Seed beetle

Tissue damaged: seeds 
Effect: The adults lay eggs on the pods, and the larvae bore into the seed, often completely destroying the seed and hence preventing germination.

Species affected: Acacia nilotica, $A$. catechu

\section{Chrysobothris sp.}

Common name: Jewel beetle

Tissue damaged: root

Effect: This beetle bore into the root tissue damaging the plant and destroying the timber.

Species affected: Acacia nilotica

\section{Heterophylla cubana}

Common name: Leucaena psyllid

Tissue damaged: shoot

Effect: It feeds on young growth and occasionally older growth and flowers. It causes dieback of terminal shoots and stunting. At times the damage can lead to defoliation and death of plants.

Species affected: Acacia nilotica

\section{Sternocera castanea}

Common name: Bark beetle

Tissue damaged: Bark

Effect: The insect bores in the bark damaging the timber production.

Species affected: Acacia senegal

9. Oxyrachis tarandus

Common name: Cow bug

Tissue damaged: Shoot

Effect: The nymphs and adults feed gregariously on the sap of the shoot.

Species affected: Acacia nilotica, $A$. catechu

10. Taragima siva

Common name: Lasiocampid moth

Tissue damaged: bark and foliage

Effect: the caterpillars feed gregariously byscrapping bark and gnaws the foliage

Species affected: Acacia nilotica, $A$. senegal

\section{Halys dentatus}

Common name: Stink bug

Tissue damaged: leaves

Effect: The bugs live in the bark of the tree and feeds on the sap of the foliage.

Species affected: Acacia nilotica, $A$. catechu

\section{Homoeocerus signatus}


Common name: Bug

Tissue damaged: sapling

Effect: Nymphs and adults of this species have been reported to cause mild damage to the sapling.

Species affected: Acacia nilotica

\section{Drosicha sp.}

Common name: Mango mealybug

Tissue damaged: shoot

Effect: The nymphs and adults cause considerable damage to young plantations.

The bug feeds on the sites of damaged older branches.

Species affected: Acacia nilotica, A. catech ${ }^{17}$

\section{Araecerus suturalis}

Common name: Coffee bean weevil

Tissue damaged: seeds

Effect: Adult causes severe damage to the stored seeds

Species affected: Acacia nilotica

\section{Celosterna scabrator}

Common name: Long-horned beetle

Tissue damaged: roots

Effect: the larvae bores into the roots hollowing them causing dieback.

Species affected: Acacia nilotica, A. catechu

\section{Chrysobothris gardnii}

Common name: wood-boring beetle

Tissue damaged: root

Effect: This beetle bore into the root tissue damaging the plant and destroying the timber.

Species affected: Acacia nilotica, $A$. catechu

\section{Diapromorpha balteata}

Common name: Cucumber beetle

Tissue damaged: Leaves

Effect: The adult feeds on leaves voraciously.

Species affected: Acacia nilotica, A. catechu

\section{Sinosylon anale}

Common name: Powder post beetle

Tissue damaged: Shoot

Effect: The insect Excavates the tunnels in transverse.

Species affected: Acacia nilotica 
19. Hamaspi doproctus cineres

Common name:

Tissue damaged: Leaves

Effect: The nymph feeds on the sap of the leaves and shoot.

Species affected: Acacia nilotica, A. catechu

20. Lacifer laca

Common name: lac insect

Tissue damaged: shoots

Effect: Feeds on the sap of succulent shoots.

Species affected: Acacia nilotica, A. catechu

21. Cryptophelebia illepida

Common name: Koa seed moth

Tissue damaged: Pods and seeds

Effect: The bug bores into the seeds and damages them.

Species affected: Acacia nilotica

22. Euproctis lunata

Common name: Castor hairy caterpillar

Tissue damaged: leaves

Effect: The larva feeds on the leaf sap.

Species affected: Acacia nilotica, $A$. catechu

23. Xyleborus sp.

Common name: Blight beetle

Tissue damaged: wood

Effect: the insect bore the tree shoots making it susceptible to fungal infections.

Species affected: Acacia nilotica, $A$. catechu

24. Casiala raptaria

Common name: tree sucking bug

Tissue damaged: Leaves

Effect: The larva feeds on the leaf sap.

Species affected: Acacia nilotica, $A$. catechu

\section{Nematodes}

Scientific name: Meloidogyne javanica and M. incognita

Common name: Root-Knot Nematode

Species affected: The roots of Acacia catechu, A. mangium and A. nilotica

Symptoms: infestation causes no specific above-ground symptoms other than stunted growth, wilting and chlorosis. On the roots, we can find galls moderate to large which crush the xylem vessels, thus interrupting the water and minerals flow to the stem tissues. 
Phytoplasma

Disease name: WITCHES BROOM

Causal organism: Phytoplasma

Species affected: $A$. mangium

Symptoms: stunted growth, shape of phyllode is modified into needle like structure abnormally sprouting shoots which give the appearance of witches broom.

\section{Conclusion}

Forest plantations are actively playing a crucial role in the forestry market for each environmental and economic reasons. These forests are primarily placed to provide raw materials. Improvement through optimizing of silvicultural methods, exploring breeding and genetics of acacias is slowly going on. Although improvement remains slow, as when compared with crops, as a result of the era at blades' rotation, more significant tree dimension as well as substantial website management, a number of achievements in breeding and genetics of Acacias have provided a tremendous impact and benefit within the functional scale of forest industries.

\section{References}

1. Kull, C. A. \& Rangan, H. Acacia exchanges: wattles, thorn trees, and the study of plant movements. Geoforum39, 1258-1272 (2008).

2. Cumo, C. M. Encyclopedia of Cultivated Plants: From Acacia to Zinnia [3 volumes]: From Acacia to Zinnia. (ABC-CLIO, 2013).

3. Seigler, D. S. \& Ebinger, J. E. Clarification of Acacia multipinnata, A. paniculata, A. scandens and A. tenuifolia. Phytologia97, 179-186 (2015).

4. Bond, W. J. Fires in the Cenozoic: a late flowering of flammable ecosystems. Front Plant SCI5, (2015).

5. Franco, M. J. \& Brea, M. First extra-Patagonian record of Podocarpaceae fossil wood in the Upper Cenozoic (Ituzaingó Formation) of Argentina. New Zealand Journal of Botany53, 103-116 (2015).

6. Miller, James. H, Chambliss, Erwin. B, and Loewenstein, Nancy. J. A field guide for the identification of invasive plants in southern forests Gen. Tech. Rep. SRS-119. Asheville, NC: US Department of Agriculture, Forest Service, Southern Research Station. 126 p (2010).

7. Wyatt. Robert, Inflorescence Architecture: How Flower Number, Arrangement, and Phenology Affect Pollination and Fruit-Set". American Journal of Botany. 69 (4): 585-594 (1982).

8. Botha, J., Witkowski, E.T.F., Shackleton, C.M., 2002. A comparison of anthropogenic and elephant disturbance on Acacia xanthophloea (fever tree) populations in the Lowveld, South Africa. Koedoe 45, 918 (2002). 
9. Mitra. S, Sundaram. R. Antioxidant activity of ethyl acetate soluble fraction of Acacia arabica bark in rats. Indian J. Pharmacol., 39(1): 33-38 (2007).

10. Sharma. A, Shetty. M, Parida. A, Adiga. S, Kamath. S. Effect of ethanolic extract of Acacia auriculiformis leaves on learning and memory in rats. Pharmacogn Res, 6(3): 246 (2014).

11. Thinh, H . Genetic variation in growth, stem straightness and branch thickness in clonal trials of Acacia auriculiformis at three contrasting sites in Vietnam. For. Ecol. Manage. 255, 156-167(2008).

12. Doran,C. Turnbull,J.W,: AustralianTreesand Shrubs: Species for Land Rehabilitation and Farm Planting in the Tropics. ACIAR(Australien Centre for International Agri- cultural Research), Canberra (1993).

13. Hiratsuka, M. Toma, T., Yamada, M., Heeriansyah, I. and Marikawa, Y. A general allometric equation for estimating biomass in Acacia mangium plantations. Proceedings of the International Conference on Tropical Forests and Climate Change. Manila, Philippines, (2003).

14. Krisnawati, H. Wang, Y. and Ades, P.K. Generalized height-diameter model for Acacia mangium Willd. plantations in South Sumatra. Journal of Forestry Research 7: 1-19 (2010).

15. Hardiyanto, E.B. and Wicaksono, A. Interrotation site management, stand growth and soil properties in Acacia mangium plantations in South Sumatra, Indonesia. In: Nambiar, EKS (ed.) Site management and productivity in tropical plantation forests. Proceedings of Workshop, Brazil, 22-26 November 2004, and Indonesia, (2008).

16. Roux, J. Threats to Wattle plantations III: diseases. Black wattle: the South African research experience (ed. by R.W. Dunlop and L.A. MacLennan), pp. 121-126. Institute for Commercial Forestry Research, Pietermaritzburg, South Africa (2002).

17. Roux, J. \& Wingfield, M.J. Ceratocystis species: emerging pathogens of non-native plantation Eucalyptus and Acacia species. Southern Forests, 71, 115-120 (2009). 